JURNAL KACAPURI

JURNAL KEILMUAN TEKNIK SIPIL

Volume 2 Nomor 2 Edisi Desember 2019

\title{
STUDI KARAKTERISTIK CAMPURAN LAPIS TIPIS ASPAL PASIR KELAS A DENGAN PENAMBAHAN SERAT SELULOSA ROADCELL-50
}

\author{
Yasruddin \\ Dosen Program Studi Teknik Sipil, Fakultas Teknik, ULM \\ E-mail : yasruddim@ulm.ac.id/ HP.+62811590673
}

\begin{abstract}
ABSTRAK
Sifat Latasir yang rentan terhadap retak-retak tentu menimbulkan pertanyaan mengenai bahan apa yang bisa meningkatkan ketahanan lapis perkerasan Latasir tersebut sehingga ketahanan terhadadap stabilitas dan durabilitasnya dapat tercapai selama umur rencana. Salah satu cara meningkatkan kinerja campuran aspal adalah dengan memodifikasi campuran aspal dengan menambahkan aditif serat selulosa Roadcell-50. Penelitian ini bertujuan untuk mengetahui pengaruh penambahan serat selulosa Roadcell-50 terhadap perubahan karakteristik Marshall dan durabilitas campuran Latasir kelas A.

Bahan yang digunakan dalam penelitian ini adalah pasir Sungai Martapura, filler, dan aspal Shell ex-Singapura. Komposisi campuran yang digunakan dalan pengujian adalah fraksi 1 (pasir sedang) sebanyak 5.99\%, fraksi 2 (pasir halus) sebanyak $83.01 \%$, filler sebanyak 11. Pengujian dilaksanakan dengan melakukan pengujian Marshall dan uji perendaman (Immertion Test) pada campuran aspal sebelum dan sesudah ditambahkan aditif sebanyak 1\%, 2\%, 3\%, 4\% terhadap variasi kadar aspal 5.5\%, 6\%, 6.5\%, 7\%, 7.5\%.

Dari hasil penelitian diketahui penambahan zat aditif ini tidak mengubah kadar aspal optimum secara signifikan tetapi mampu meningkatkan nilai indeks perendaman. Selain itu nilai stabilitas, flow, VIM, VMA meningkat seiring naiknya kadar aditif. Sementara nilai VFB dan Marshall Quotient menurun.
\end{abstract}

Kata Kunci: Latasir, Roadcell-50, Immertion Test, Flow, Marshall Quotient.

\section{ABSTRACT}

The nature of Latasir which is prone to cracking certainly raises questions about what materials can increase the resistance of the Latasir pavement layers so that resistance to its stability and durability can be achieved during the life of the plan. One way to improve the performance of asphalt mixes is to modify the asphalt mixture by adding Roadcell-50 cellulose fiber additives. This study aims to determine the effect of the addition of Roadcell-50 cellulose fibers to changes in Marshall characteristics and the durability of the Class A Latasir mixture.

The materials used in this research are Martapura River sand, fillers, and Shell ex-Singapore asphalt. The composition of the mixture used in the test is fraction 1 (medium sand) as much as $5.99 \%$, fraction 2 (fine sand) as much as $83.01 \%$, filler as much as 11 . Testing is carried out by 
JURNAL KACAPURI

JURNAL KEILMUAN TEKNIK SIPIL

Volume 2 Nomor 2 Edisi Desember 2019

conducting Marshall testing and immersion test (asphalt mixture) before and after additives added as much as 1\%, 2\%, 3\%, 4\% to the variation of asphalt levels 5.5\%, 6\%, 6.5\%, 7\%, 7.5\%.

From the results of the study note that the addition of this additive does not significantly change the optimum asphalt content but can increase the value of the immersion index. Besides the value of stability, flow, VIM, VMA increases with increasing levels of additives. While VFB and Marshall Quotient values decreased.

Keywords: Latasir, Roadcell-50, Immertion Test, Flow, Marshall Quotient.

\section{PENDAHULUAN}

Kondisi iklim tropis di Indonesia dimana suhu yang tinggi dan dan curah hujan yang besar menjadi faktor-faktor penyebab kerusakan dini perkerasan beraspal disamping faktor lainnya seperti peningkatan volume lalu lintas yang tidak terkendali. Jenis-jenis kerusakan yang sering ditemui untuk Lapisan Tipis Aspal Pasir (Latasir) biasanya adalah deformasi permanen dan retak-retak (cracking).

Salah satu cara yang telah banyak dilakukan untuk meningkatkan ketahanan lapis perkerasan adalah menambahkan material-material aditif kedalamnya. Bahan aditif tersebut umumnya mengandung serat selulosa. Material serat selulosa ini telah dikembangkan di banyak negara seperti, Arbocel dan Technocel-1004 di Jerman, CF-31500 di USA, dan di Indonesia ada serat Roadcell-50 yang diproduksi oleh PT. Olah Bumi Mandiri Jakarta yang harganya lebih murah dari produk-produk impor sejenis.

Penelitian ini mengkaji penggunaan bahan Roadcell-50 pada campuran Lapis Tipis Aspal Pasir (Latasir) Kelas A. Tujuan penelitian ini adalah mengetahui pengaruh penambahan serat Roadcell50 pada karakteristik campuran Latasir kelas A. Tujuan penelitian ini adalah :

1. Mengetahui pengaruh penambahan serat Roadcell-50 terhadap karakteristik Marshall campuran Latasir A .

2. Mengetahui durabilitas yang terjadi pada Latasir A dengan campuran Roadcell-50.

\section{TINJAUAN PUSTAKA}

\section{Bahan Penelitian}

Bahan-bahan yang akan digunakan dalam penelitian ini antara lain: Agregat pengisi (filler) yang digunakan adalah abu batu. Agregat halus menggunakan pasir sungai Martapura. Untuk bahan aspal menggunakan aspal Shell Ex-Singapura dengan penetrasi 60/70 dan Aditif Serat Selulosa Roadcell-50.

\section{Aspal Pen. 60/70}

Aspal dikenal sebagai suatu material yang bersifat viskos atau padat, berwarna hitam atau coklat, yang mempunyai daya lekat (adhesif). Aspal merupakan material hydrocarbon hasil lanjutan residu proses destilasi minyak bumi yang bersifat thermoplastis. Jenis aspal yang digunakan dalam 
JURNAL KACAPURI

JURNAL KEILMUAN TEKNIK SIPIL

Volume 2 Nomor 2 Edisi Desember 2019

penelitian adalah aspal SHELL Singapura pen. 60/70. Adapun spesifikasi aspal SHELL Singapura pen. 60/70 bisa dilihat pada Tabel 1 .

Tabel 1. Spesifikasi aspal pen. 60/70

\begin{tabular}{|c|c|c|c|}
\hline No & Jenis Pengujian & Metode & Type I Aspal Pen 60-70 \\
\hline 1 & Penetrasi pada $25^{\circ} \mathrm{C}$ & SNI 06-2456-1991 & $60-70$ \\
\hline 2 & Viskositas pada $135^{\circ} \mathrm{C}$ & SNI 06-6441-2000 & 385 \\
\hline 3 & Titik lembek $\left({ }^{\circ} \mathrm{C}\right)$ & SNI 06-2434-1991 & $\geq 48$ \\
\hline 4 & Indeks penetrasi & - & $\geq-1,0$ \\
\hline 5 & Daktilitas pada $25^{\circ} \mathrm{C}(\mathrm{cm})$ & SNI 06-2432-1991 & $\geq 100$ \\
\hline 6 & Titik nyala $\left({ }^{\circ} \mathrm{C}\right)$ & SNI 06-2433-1991 & $\geq 232$ \\
\hline 7 & Kelarutan dlm Toulene (\%) & ASTM D5546 & $\geq 99$ \\
\hline 8 & Berat jenis & SNI 06-2441-1991 & $\geq 1,0$ \\
\hline 9 & Stabilitas penyimpanan $\left({ }^{\circ} \mathrm{C}\right)$ & ASTM D 5976 part 6.1 & - \\
\hline \multicolumn{4}{|c|}{ Pengujian Residu hasil TFOT atau RTFOT: } \\
\hline 10 & Berat yang hilang $(\%)$ & SNI 06-2441-1991 & $\leq 0,8$ \\
\hline 11 & Penetrasi pd $25^{\circ} \mathrm{C}$ & SNI 06-2456-1991 & $\geq 54$ \\
\hline 12 & Indeks penetrasi & - & $\geq-1,0$ \\
\hline 13 & $\begin{array}{l}\text { Keelastisan setelah } \\
\text { pengembalian }(\%)\end{array}$ & AASHTO T 301-98 & - \\
\hline 14 & Daktilitas pada $25^{\circ} \mathrm{C}(\mathrm{cm})$ & SNI 06-2432-1991 & $\geq 100$ \\
\hline 15 & $\begin{array}{l}\text { Partikel yg lebih halus dari } 150 \\
\text { micron }\end{array}$ & & \\
\hline
\end{tabular}

\section{Agregat Halus}

Agregat halus dari masing-masing sumber harus terdiri atas pasir alam atau hasil pemecah batu dan harus disediakan dalam ukuran nominal maksimum 2,36 mm. Sampel yang dipergunakan dalam pemeriksaan adalah agregat yang lewat saringan No. $8(2,36 \mathrm{~mm})$ dan tertahan saringan no. $200(75 \mu \mathrm{m})$ sesuai standar ASTM.

\section{Data Roadcell-50}

Roadcell-50 yang digunakan untuk serat selulosa Aleophilick Micronized dan sebagai bahan stabilisasi bagi aspal pada campuran aspal. Serat selulosa dapat meningkatkan modulus kekakuan, meningkatkan ketahanan terhadap rutting dan mengurangi retak-retak pada lapisan aspal. Serat selulosa juga bisa meningkatkan kadar aspal optimum yang sekaligus meningkatkan durabilitas. Serat selulosa merupakan bahan aditif yang bekerja secara fisik dan mekanik. Stabilitas secara fisik berarti dapat menaikkan titik lembek aspal, viskositas dan menurunkan penetrasinya. Stabilitas secara mekanik yaitu meningkatkan kekakuan antara aspal dengan agregat sebagai efek penulangan tiga dimensi oleh serat selulosa. Adapun karakteristik Roadcell-50 bisa dilihat pada Tabel 2. 
JURNAL KACAPURI

JURNAL KEILMUAN TEKNIK SIPIL

Volume 2 Nomor 2 Edisi Desember 2019

Tabel 2. Karakteristik Roadcell-50

\begin{tabular}{|l|l|c|c|}
\hline No & \multicolumn{1}{|c|}{ Karakteristik } & Satuan & Spesifikasi \\
\hline 1 & Kadar Selulosa & $\%$ & 90 \\
\hline 2 & Berat isi gembur/curah & Gr/ltr & 30 \\
\hline 3 & Kadar air & $\%$ & - \\
\hline 4 & PH & - & $7 \pm 1$ \\
\hline 5 & Ukuran partikel $:<800 \mu,<40 \mu$ dan $<32 \mu$ & $\%$ & - \\
\hline 6 & Panjang serat maksimum & $\mu$ & 6000 \\
\hline 7 & Panjang serat rerata & $\mu$ & 1500 \\
\hline 8 & Tebal serat rerata & $\mu$ & 40 \\
\hline 9 & Berat jenis & - & - \\
\hline 10 & Residu pada pemanasan $250^{\circ} \mathrm{C}$ & $\%$ & 5 \\
\hline 11 & Ketahanan terhadap asam alkali & - & Baik \\
\hline
\end{tabular}

\section{METODE PENELITIAN}

Dalam penelitian ini metode yang digunakan meliputi pengujian agregat dan aspal, pengolahan data Marshall dan data pengujian perendaman untuk mendapatkan nilai Kadar Aspal Optimum dan pengaruh penambahan aditif Roadcell-50 pada campuran.

\section{Pengujian Aspal}

Bahan aspal harus diesktraksi dari benda uji sesuai cara SNI 03-6894-2002. Setelah konsentrasi larutan aspal yang terekstraksi mencapai $200 \mathrm{~mm}$, partikel mineral yang terkandung harus dipindahkan ke dalam sentrifugal. Pemindahan ini dianggap memenuhi bilamana kadar abu dalam bahan aspal yang diperoleh kembali tidak melebihi $1 \%$ (dengan pengapian). Ada pun pengujian aspal sebagai berikut:

1. Pengujian Titik Nyala dan titik bakar Aspal

2. Pemeriksaan Bahan-Bahan Bitumen

3. Pengujian kehilangan berat aspal

4. Pengujian Daktilitas (ducktility test) Pengujian Berat Jenis Aspal

5. Pengujian Titik Lembek Aspal dan Ter

\section{Pengujian Filler}

Bahan pengisi harus bebas dari semua bahan yang tidak dikehendaki. Bahan pengisi yang ditambahakan harus kering dan bebas dari gumpalan-gumpalan. Pengujian Filler meliputi Pengujian Jumlah Bahan Dalam Agregat Yang Lolos Saringan Nomor $200(0,075 \mathrm{~mm})$ yaitu banyaknya bahan yang lolos saringan nomor $200(0,075 \mathrm{~mm})$ sesudah agregat dicuci sampai air cucian menjadi jernih. 
JURNAL KACAPURI

JURNAL KEILMUAN TEKNIK SIPIL

Volume 2 Nomor 2 Edisi Desember 2019

\section{Pengujian Agregat Halus}

Pemeriksaan ini dimaksudkan untuk menentukan berat jenis (bulk), berat jenis kering permukaan jenuh (Saturace Surface Dry = SSD), berat jenis semu (Apparent) dan penyerapan dari agregat kasar.

\section{Menentukan Kadar Aspal Rencana (Pb)}

Perkiraan awal kadar aspal rancangan dapat diperoleh dari rumus dibawah ini.

Dimana :

$$
\mathrm{Pb}=0,035(\% \mathrm{CA})+0,045(\% \mathrm{FA})+0,18(\% \text { Filler })+\mathrm{k}
$$

$\mathrm{Pb}=$ Kadar aspal rencana

$\mathrm{CA}=$ Agregat kasar tertahan saringan No.8

$\mathrm{FA}=$ Agregat halus saringan No.8 dan Tertahan No.200

$\mathrm{F}=$ Agregat halus lolos saringan No.200

\section{Pengujian Marshall}

Pemeriksaan ini dimaksudkan untuk menentukan ketahanan (stabilitas) terhadap kelelehan plastis (flow) dari campuran aspal. Ada tahapan-tahapan pengujian Marshall sebagai berikut:

1. Dilakukan penimbangan agregat sesuai dengan prosentase pada target gradasi yang diinginkan untuk masing-masing fraksi dengan berat campuran kira-kira 1200 gram.

2. Dilakukan pemanasan aspal untuk pencampuran pada viskositas kinematik $100 \pm 10$ centistokes.

3. Setelah temperatur pemadatan tercapai yaitu pada viskositas kinematik $100 \pm 10$ centistokes, maka campuran tersebut dimasukkan ke dalam cetakan yang telah dipanasi pada temperatur 100 hingga $170^{\circ}$, serta bagian bawah cetakan diberi sepotong kertas filter atau kertas lilin (waxed paper) yang telah dipotong sesuai dengan diameter cetakan sambil ditusuk-tusuk dengan spatula sebanyak 15 kali di bagian tepi dan 10 kali di bagian tengah.

4. Pemadatan standar dilakukan dengan pemadat manual dengan jumlah tumbukan $50 \mathrm{kali}$ di bagian sisi atas kemudian dibalik dan sisi bagian bawah juga ditumbuk sebanyak 50 kali.

5. Setelah proses pemadatan selesai benda uji didiamkan agar suhunya turun.

6. Benda uji dibersihkan dari kotoran yang menempel dan diukur tinggi benda uji dengan ketelitian 0,1 $\mathrm{mm}$ dan ditimbang beratnya di udara.

7. Benda uji direndam dalam air selama 10-24 jam supaya jenuh.

8. Setelah jenuh benda uji ditimbang dalam air.

9. Benda uji dikeluarkan dari bak dan dikeringkan dengan kain pada permukaan agar kondisi kering permukaan jenuh (saturated surface dry, SSD) kemudian ditimbang.

10. Benda uji direndam dalam bak perendaman pada suhu $60 \pm 1^{\circ} \mathrm{C}$ selama 30 hingga 40 menit. Untuk uji perendaman mendapatkan stabilitas sisa pada suhu $60 \pm 1^{\circ} \mathrm{C}$ selama 24 jam.

11. Benda uji dikeluarkan dari bak perendam, lalu diletakkan tepat di tengah pada bagian bawah kepala penekan kemudian bagian atas kepala diletakkan dengan memasukkan lewat batang penuntun.

12. Setelah pemasangan sudah lengkap maka diletakkan tepat di tengah alat pembebanan. Kemudian arloji kelelehan (flow meter) dipasang pada dudukan di atas salah satu batang penuntun. 
JURNAL KACAPURI

13. Kepala penekan dinaikkan hingga menyentuh atas cincin penguji, kemudian diatur kedudukan jarum arloji penekan dan arloji kelelehan pada angka nol.

14. Pembebanan dilakukan dengan kecepatan tetap $51 \mathrm{~mm}$ (2 inch) per menit, hingga kegagalan benda uji terjadi yaitu pada saat arloji pembebanan berhenti dan mulai kembali berputar menurun. Titik pembacaan pada saat benda uji mengalami kegagalan adalah merupakan nilai stabilitas Marshall.

15. Setelah pengujian selesai, kepala penekan diambil, bagian atas dibuka dan benda uji dikeluarkan. Waktu yang diperlukan dari saat diangkatnya benda uji dari rendaman air sampai tercapainya beban maksimum tidak boleh melebihi 60 detik.

Hasil perhitungan dari data-data yang diperoleh selama percobaan dapat dilihat pada tabel hasil perhitungan. Adapun rumus - rumus yang digunakan dalam perhitungan tersebut adalah :

1. Persen Aspal terhadap Campuran (\%)

$\frac{\% \text { aspal terhadap berat agregat }}{(\% \text { aspal terhadap berat agregat }+100 \%)} \times 100 \%$

2. Berat Isi $\left(\mathrm{m}^{3}\right)$

BeratIsi $=\frac{\text { Berat benda uji }}{\text { isi benda uji }}$

3. Stabilitas ( kg )

"Pembacaan arloji tekan x Angka korelasi beban

4. Pelelehan / Flow ( $\mathrm{mm}$ )

"Dibaca pada arloji pengukur pelelehan dalam satuan mm."

5. Berat Jenis Maksimum (GS Max) teoritis

$\frac{100}{\frac{\% \text { agregat }}{\text { Bjagregat }}+\frac{\% \text { aspal }}{\mathrm{Bj} \text { aspal }}}$

6. Persentase Jumlah Kandungan Rongga $=100$ - volume aspal - volume agregat

7. Persentase Rongga terhadap Agregat $(\mathrm{VMA})=100-$ volume agregat

8. Persentase Rongga terisi Aspal (VFB)= $100 \mathrm{x}$ volume aspal

Persentase rongga thd agregat

9. Persentase Rongga terhadap campuran (VIM) $=$

$100-\frac{100 \times \text { berat isi campuran }}{\text { Bj teoritis }}$

10. Marshall Quation (MQ)

$\mathrm{MQ}=\frac{q}{102 \times r}$

Dimana :

$\mathrm{q}=$ stabilitas $(\mathrm{kg})$

$\mathrm{r}=$ kelelehan $(\mathrm{mm})$ 
JURNAL KACAPURI

JURNAL KEILMUAN TEKNIK SIPIL

Volume 2 Nomor 2 Edisi Desember 2019

Adapun persyaratan sifat Marshall yang harus dipenuhi oleh campuran adalah sebagai berikut pada Tabel 4.

Tabel 4. Persyaratan sifat Marshall campuran

\begin{tabular}{|c|c|c|}
\hline \multirow{2}{*}{\multicolumn{2}{|c|}{ Sifat-sifat Campuran }} & \multirow{3}{*}{$\begin{array}{c}\text { Latasir } \\
\text { Kelas A \& B } \\
2,0\end{array}$} \\
\hline & & \\
\hline Penyerapan aspal (\%) & Maks. & \\
\hline Jumlah tumbukan per bidang & & 50 \\
\hline \multirow{2}{*}{ Rongga dalam campuran (\%) ${ }^{(2)}$} & Min. & 3,0 \\
\hline & Maks. & 6,0 \\
\hline Rongga dalam Agregat (VMA) (\%) & Min. & 20 \\
\hline Rongga terisi aspal (\%) & Min. & 75 \\
\hline Stabilitas Marshall (kg) & Min. & 200 \\
\hline \multirow{2}{*}{ Pelelehan (mm) } & Min. & 2 \\
\hline & Maks. & 3 \\
\hline Marshall Quotient (kg/mm) & Min. & 80 \\
\hline Stabilitas Marshall Sisa (\%) setelah perendaman selama 24 jam, $60^{\circ} \mathrm{C}^{(3)}$ & Min. & 90 \\
\hline
\end{tabular}

\section{Pengujian Durabilitas/Perendaman}

Uji perendaman dilakukan pada temperatur $60 \pm 1^{\circ} \mathrm{C}$ selama 24 jam. Masing-masing golongan terdiri dari 2 sampel yang direndam pada bak perendaman untuk semua variasi kadar aspal. Spesifikasi Departemen Permukiman dan Prasarana Wilayah untuk mengevaluasi keawetan campuran adalah pengujian Marshall perendaman di dalam air pada suhu $60^{\circ} \mathrm{C}$ selama 24 jam. Perbandingan stabilitas yang direndam dengan stabilitas standar, dinyatakan sebagai persen, dan disebut Indeks Stabilitas Sisa (IRS), dan dihitung sebagai berikut :

$I R S=(M s i / M S s) \times 100 \%$

Dimana : IRS ((Index Retained Strength), Msi (Stabilitas Marshall) setelah perendaman 24 jam suhu ruang $60 \pm 1^{\circ} \mathrm{C}$, dan MSs (Stabilitas Marshall standar pada perendaman selama $30 \pm 1$ menit suhu $60^{\circ} \mathrm{C},(\mathrm{kg})$

\section{HASIL DAN PEMBAHASAN}

Hasil dari pengujian laboraturium pada sampel aspal SHELL Singapura pen. 60/70 yang digunakan bisa dilihat pada Tabel 5.

Tabel 5. Hasil Pengujian Aspal

\begin{tabular}{|l|c|c|c|c|}
\hline \multicolumn{1}{|c|}{ Pemeriksaan } & Metode Pengujian & Spesifikasi & Hasil & Ket \\
\hline Penetrasi & SNI 06-2456-1991 & $60-79 \mathrm{~mm}$ & $68 \mathrm{~mm}$ & OK \\
\hline Titik lembek & SNI 06-2434-1991 & Min. $48^{\circ} \mathrm{C}$ & $56,75^{\circ} \mathrm{C}$ & OK \\
\hline Titik nyala, titik bakar & SNI 06-2433-1991 & Min. $232^{\circ} \mathrm{C}$ & $256^{\circ} \mathrm{C}, 258^{\circ} \mathrm{C}$ & OK \\
\hline Daktilitas & SNI 06-2432-1991 & Min. $100 \mathrm{~cm}$ & $100 \mathrm{~cm}$ & OK \\
\hline Berat jenis & SNI 06-2441-1991 & Min. 1 & 1,06 & OK \\
\hline
\end{tabular}


JURNAL KACAPURI

JURNAL KEILMUAN TEKNIK SIPIL

Volume 2 Nomor 2 Edisi Desember 2019

Hasil pengujian pada filler yaitu analisa saringan dengan menggunakan saringan no.50 dan no.200. filler harus merupakan agregat lolos saringan no.50 minimal $95 \%$ dan juga lolos saringan no.200. dari pengujian terdahulu didapatkan nilai berat jenis (bulk) filler $=2,263$ dan berat jenis semu $=2,353$.

Hasil pengujian agregat halus adalah hasil dari pengujian laboraturium pada sampel pasir sungai Martapura bisa dilihat pada Tabel 6.

Tabel 6. Hasil Pengujian Agregat Halus

\begin{tabular}{|l|l|c|c|c|}
\hline \multicolumn{1}{|c|}{ Pengujian } & Metode & Spesifikasi & Hasil & Ket \\
\hline Berat jenis semu & SNI 03-1970-1990 & $\geq 2,5 \%$ & $2,690 \%$ & OK \\
\hline Berat jenis jenuh & SNI 03-1970-1990 & $\geq 2,5 \%$ & $2,681 \%$ & OK \\
\hline Berat jenis & SNI 03-1970-1990 & $\geq 2,5 \%$ & $2,634 \%$ & OK \\
\hline Penyerapan air & SNI 03-1970-1990 & $\leq 3 \%$ & $1,792 \%$ & OK \\
\hline Sand equivalent & SNI 03-4428-1997 & $\geq 45 \%$ & $98,81 \%$ & OK \\
\hline
\end{tabular}

Hasil pengujian analisa saringan bisa dilihat pada Tabel 7 .

Tabel 7. Hasil Analisa Saringan

\begin{tabular}{|c|c|c|c|c|c|c|c|}
\hline \multirow{2}{*}{$\begin{array}{c}\text { Nomor } \\
\text { Saringan }\end{array}$} & \multicolumn{2}{|c|}{ Fraksi 1 } & \multicolumn{2}{|c|}{ Fraksi 2 } & \multicolumn{2}{|c|}{ Filler } & \multirow{2}{*}{$\begin{array}{c}\text { Total } \\
(\%)\end{array}$} \\
\cline { 2 - 7 } & \multicolumn{2}{|c|}{$5,99 \%$} & \multicolumn{2}{|c|}{$83,01 \%$} & \multicolumn{2}{c|}{$11 \%$} & 100 \\
\hline $3 / 4 "$ & 100 & 5,99 & 100 & 83,0 & 100 & 11 & 100 \\
\hline $3 / 8 "$ & 16,46 & 0,99 & 100 & 83,0 & 100 & 11 & 95 \\
\hline $200 "$ & 0,23 & 0,01 & 0,89 & 0,74 & 100 & 11 & 12 \\
\hline
\end{tabular}

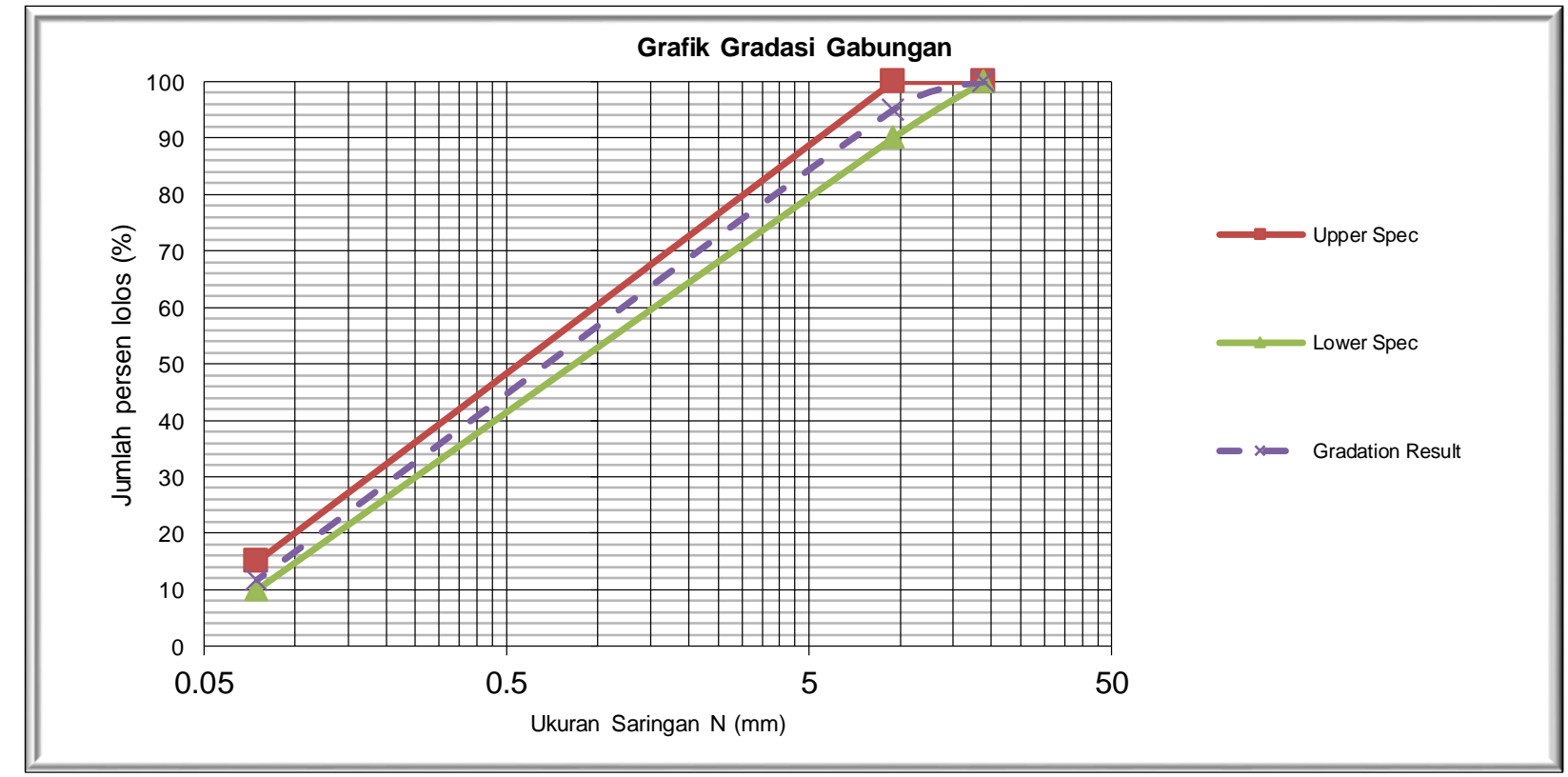

Gambar 2. Grafik Analisa Saringan 
JURNAL KACAPURI

JURNAL KEILMUAN TEKNIK SIPIL

Volume 2 Nomor 2 Edisi Desember 2019

Kadar Aspal Rencana (Pb) adalah perkiraan awal kadar aspal rancangan yang diperoleh $\mathbf{P b}=\mathbf{6 , 5} \%$. Maka sampel yang akan dibuat menggunakan variasi kadar aspal 5,5\% ; $6 \% ; 6,5 \%$ ; 7\% ; 7,5\% sesuai metode Asphalt Institute yang mengasumsikan variasi kadar aspal terdiri dari 5 variasi dengan rentang antara 0,5 sampai 1.

Hasil Pengujian Marshall didapatkan data seperti pada Tabel 8 yang akan dihitung dengan rumus di atas.

Tabel 8. Data Pengujian Marshall

\begin{tabular}{|c|c|c|c|c|c|c|c|c|c|c|c|c|c|c|c|}
\hline \multirow{3}{*}{$\begin{array}{l}\text { Kadar } \\
\text { Aspal } \\
(\%)\end{array}$} & \multirow{2}{*}{\multicolumn{3}{|c|}{ Konvensional }} & \multicolumn{12}{|c|}{ Dengan Aditif Roadcell-50 } \\
\hline & & & & \multicolumn{3}{|c|}{$1 \%$} & \multicolumn{3}{|c|}{$2 \%$} & \multicolumn{3}{|c|}{$3 \%$} & \multicolumn{3}{|c|}{$4 \%$} \\
\hline & $\begin{array}{c}\text { H } \\
\text { (min) }\end{array}$ & Stek & $\begin{array}{l}\text { Flaw } \\
(\mathrm{mm})\end{array}$ & $\begin{array}{l}H \\
\text { (m) }\end{array}$ & $\begin{array}{l}\text { Stat } \\
\text { (kz) }\end{array}$ & $\begin{array}{l}\text { Flaw } \\
\text { (min) }\end{array}$ & $\stackrel{\text { म }}{\mathrm{man}}$ & $\begin{array}{l}\text { Stat } \\
(\mathrm{kg})\end{array}$ & $\begin{array}{l}\text { Flew } \\
\text { (min) }\end{array}$ & $\begin{array}{l}\text { H } \\
\text { (m) }\end{array}$ & $\begin{array}{l}\text { Stet } \\
(\mathrm{kg})\end{array}$ & $\begin{array}{l}\text { Flaw } \\
\text { (mm) }\end{array}$ & $\stackrel{\text { म }}{\mathrm{m}}$ & $\begin{array}{l}\text { Stab } \\
(\mathrm{kg})\end{array}$ & $\begin{array}{l}\text { Flan: } \\
(\mathrm{mm})\end{array}$ \\
\hline \multirow{2}{*}{5,5} & 67,7 & 623 & 2,00 & 69,3 & 720 & 2,24 & 67 & 745 & 2,75 & 65,7 & 935 & 2 & 64,7 & 900 & 2,10 \\
\hline & 67,3 & 700 & 2,11 & 69 & 830 & 3 & 68,3 & 695 & 2,10 & 66,7 & 855 & 2,35 & 65,7 & 790 & 1,91 \\
\hline \multirow{2}{*}{6} & 68 & 760 & 2,24 & 68,3 & 795 & 259 & 66,3 & 900 & 2,70 & 64 & $12 \mathrm{ss}$ & 2.25 & 63,7 & 1120 & 2,20 \\
\hline & 66,7 & 500 & 2,21 & 68,3 & 935 & 2,88 & 65,7 & 935 & 2,90 & 63 & 1270 & 2,79 & 63,3 & 1210 & 220 \\
\hline \multirow{2}{*}{6,5} & 65,7 & 695 & 2,60 & 67 & 990 & 2,70 & 65 & 990 & 2,75 & 61,7 & 1265 & 2,5 & 62,3 & 1255 & 2,34 \\
\hline & 68,7 & 905 & 255 & 66,7 & 958 & 2,90 & 65,7 & 910 & 2,95 & 63 & 1320 & 2,78 & 62,3 & 1285 & 2,44 \\
\hline \multirow{2}{*}{7} & 66 & 900 & 3 & 66,3 & 825 & 2,90 & 64,7 & 1010 & 2,95 & 64 & 970 & 2,95 & 63 & 1000 & 3,00 \\
\hline & 67 & 785 & 2,64 & 65,3 & 835 & 2,90 & 64,7 & 985 & 2,90 & 64 & 900 & 3 & 63,7 & 910 & 2,87 \\
\hline \multirow{2}{*}{7,5} & 65,7 & 790 & 3,12 & 66,3 & $\$ 10$ & 3,60 & 64 & 925 & 2,90 & 62,3 & 500 & 3,40 & 63 & 790 & 3,05 \\
\hline & 65 & $75 s$ & 3,06 & 66,7 & 990 & 3,20 & 63,3 & 920 & 3,10 & 63,3 & 995 & 3,70 & 62,3 & 895 & 3,00 \\
\hline
\end{tabular}

Setelah dihitung dengan rumus perhitungan Marshall maka akan didapat hasil pada Tabel 9 sebagai berikut : 
JURNAL KACAPURI

JURNAL KEILMUAN TEKNIK SIPIL

Volume 2 Nomor 2 Edisi Desember 2019

Tabel 9. Hasil perhitungan Marshall

\begin{tabular}{|c|c|c|c|c|c|c|c|}
\hline \multirow{2}{*}{$\begin{array}{c}\text { Karakteristik } \\
\text { Campuran }\end{array}$} & \multirow{2}{*}{ Campuran } & \multicolumn{6}{|c|}{ Kadar Aspal (\%) } \\
\hline & & & 5.5 & 6 & 6.5 & 7 & 7.5 \\
\hline \multirow[t]{5}{*}{ VIM (\%) } & \multicolumn{2}{|c|}{ Konvensional } & 5.442 & 4.711 & 5.921 & 5.345 & 4.184 \\
\hline & \multirow[t]{4}{*}{ Aditif (\%) } & 1 & 5.74 & 5.116 & 5.899 & 5.729 & 4.588 \\
\hline & & 2 & 5.57 & 5.008 & 5.851 & 4.827 & 4.85 \\
\hline & & 3 & 5.844 & 5.164 & 5.8 & 5.128 & 5.17 \\
\hline & & 4 & 5.164 & 5.031 & 5.795 & 5.647 & 6.313 \\
\hline \multirow[t]{5}{*}{ VMA (\%) } & \multicolumn{2}{|c|}{ Konvensional } & 17.484 & 17.858 & 19.886 & 20.373 & 20.373 \\
\hline & \multirow[t]{4}{*}{ Aditif (\%) } & 1 & 17.744 & 18.208 & 19.867 & 20.696 & 20.708 \\
\hline & & 2 & 17.596 & 18.114 & 19.826 & 19.937 & 20.926 \\
\hline & & 3 & 17.835 & 18.249 & 19.783 & 20.191 & 21.192 \\
\hline & & 4 & 17.242 & 18.134 & 19.779 & 20.628 & 22.142 \\
\hline \multirow[t]{5}{*}{ VFB (\%) } & \multicolumn{2}{|c|}{ Konvensional } & 72.895 & 78.319 & 75.141 & 79.322 & 85.928 \\
\hline & \multirow[t]{4}{*}{ Aditif (\%) } & 1 & 71.594 & 76.498 & 75.202 & 77.845 & 84.183 \\
\hline & & 2 & 72.378 & 76.973 & 75.407 & 81.504 & 83.276 \\
\hline & & 3 & 71.218 & 76.28 & 75.627 & 80.217 & 81.908 \\
\hline & & 4 & 74.129 & 76.95 & 75.622 & 78.127 & 77.316 \\
\hline \multirow[t]{5}{*}{ Stabilitas ( $\mathrm{kg}$ ) } & \multicolumn{2}{|c|}{ Konvensional } & 708.51 & 838.65 & 1008.7 & 869.05 & 851.22 \\
\hline & \multirow[t]{4}{*}{ Aditif (\%) } & 1 & 807.83 & 888.7 & 1034.7 & 926.49 & 985.32 \\
\hline & & 2 & 768.76 & 1019.2 & 1075 & 1149.7 & 1108.7 \\
\hline & & 3 & 990.05 & 1506.4 & 1628.5 & 1098.5 & 1053.7 \\
\hline & & 4 & 960.85 & 1407.3 & 1597.5 & 1143.7 & 1046.8 \\
\hline \multirow[t]{5}{*}{ Flow $(\mathrm{mm})$} & \multicolumn{2}{|c|}{ Konvensional } & 2.055 & 2.225 & 2.575 & 2.82 & 3.09 \\
\hline & \multirow[t]{4}{*}{ Aditif (\%) } & 1 & 2.62 & 2.735 & 2.8 & 2.9 & 3.4 \\
\hline & & 2 & 2.425 & 2.8 & 2.85 & 2.925 & 3 \\
\hline & & 3 & 2.175 & 2.52 & 2.64 & 2.975 & 3.55 \\
\hline & & 4 & 2.005 & 2.2 & 2.39 & 2.935 & 3.03 \\
\hline \multirow[t]{5}{*}{ MQ (kN/mm) } & \multicolumn{2}{|c|}{ Konvensional } & 3.377 & 3.696 & 3.841 & 3.029 & 2.701 \\
\hline & \multirow[t]{4}{*}{ Aditif (\%) } & 1 & 3.055 & 3.177 & 3.627 & 3.132 & 2.867 \\
\hline & & 2 & 3.144 & 3.569 & 3.709 & 3.853 & 3.625 \\
\hline & & 3 & 4.513 & 5.9 & 6.063 & 3.621 & 2.91 \\
\hline & & 4 & 4.691 & 6.272 & 6.554 & 3.818 & 3.395 \\
\hline
\end{tabular}

Menentukan Kadar Aspal Optimum adalah nilai pada Tabel 9 adalah hasil perhitungan Marshall yang sudah lengkap, kemudian diplot pada grafik Marshall untuk menentukan kadar aspal optimumnya.

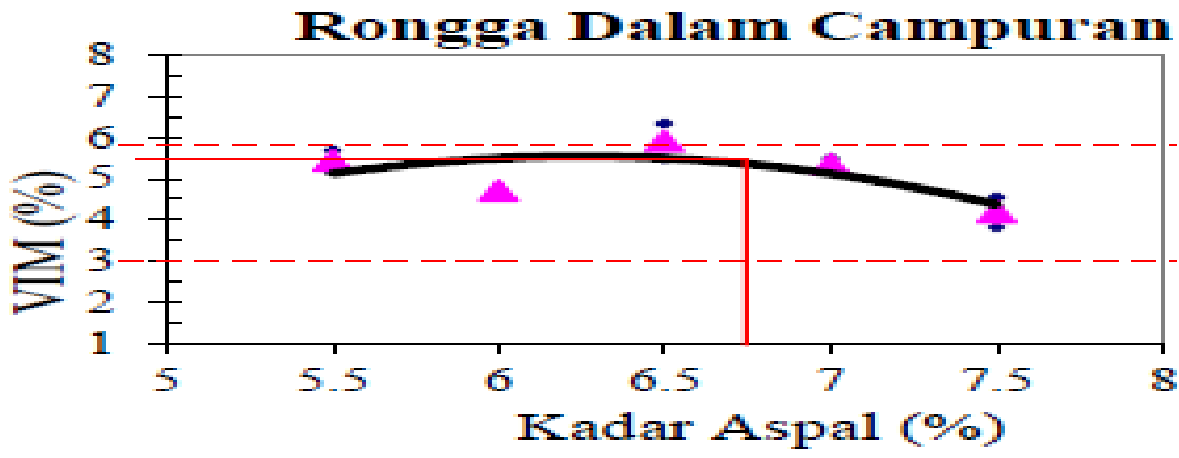

Gambar 3. Hubungan \% aspal dengan VIM Latasir Konvensional 
JURNAL KACAPURI

JURNAL KEILMUAN TEKNIK SIPIL

Volume 2 Nomor 2 Edisi Desember 2019

Batas spesifikasi nilai VIM untuk campuran Latasir yaitu minimal 3,0 dan maksimal 6,0. Pada campuran konvensional kadar aspal yang memenuhi spesifikasi untuk VIM adalah kadar aspal $5,5 \%-7,5 \%$ (lihat Gambar 3).

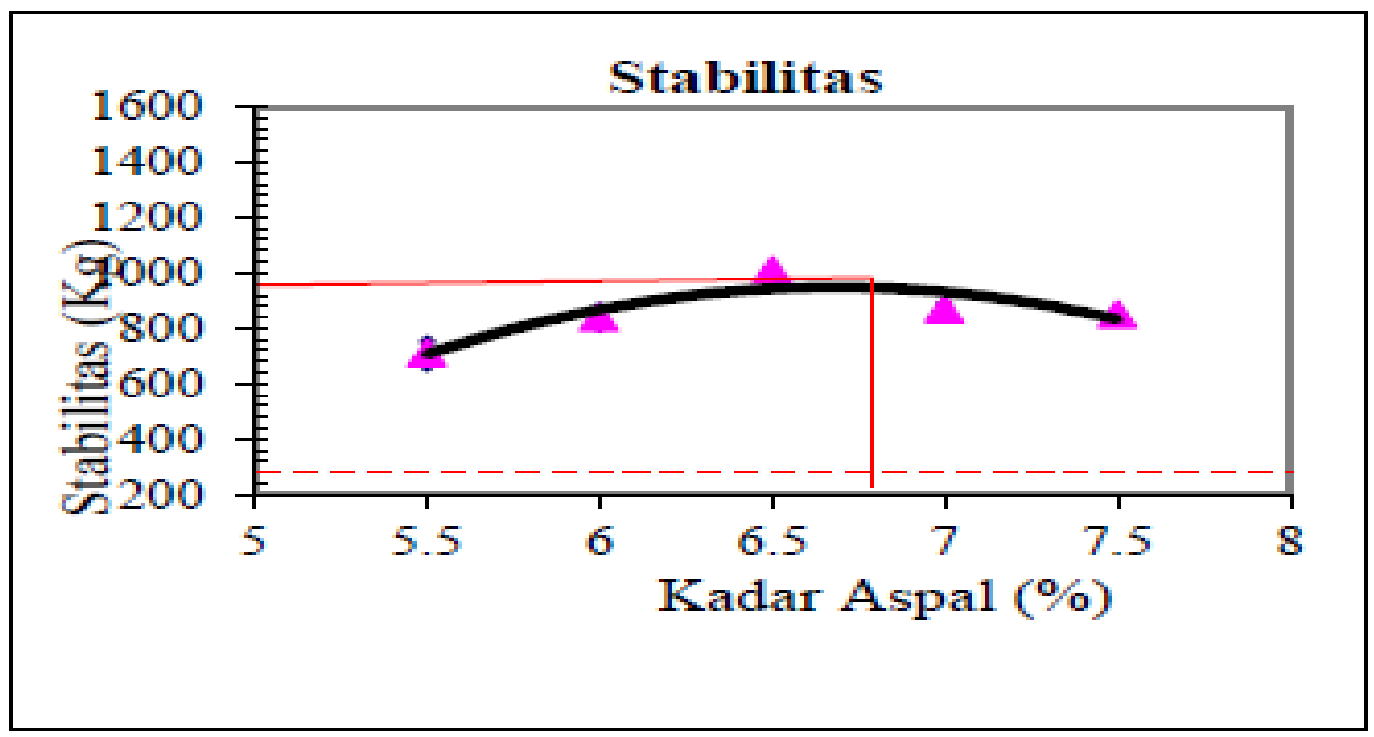

Gambar 4. Hubungan \% Aspal dengan Stabilitas Latasir Konvensional

Persyaratan Spesifikasi untuk batas nilai stabilitas untuk campuran Latasir yaitu minimal $200 \mathrm{~kg}$. Untuk campuran konvensional kadar aspal yang memenuhi spesifikasi yaitu pada kadar aspal $5,5 \%-7,5 \%$ (lihat Gambar 4).

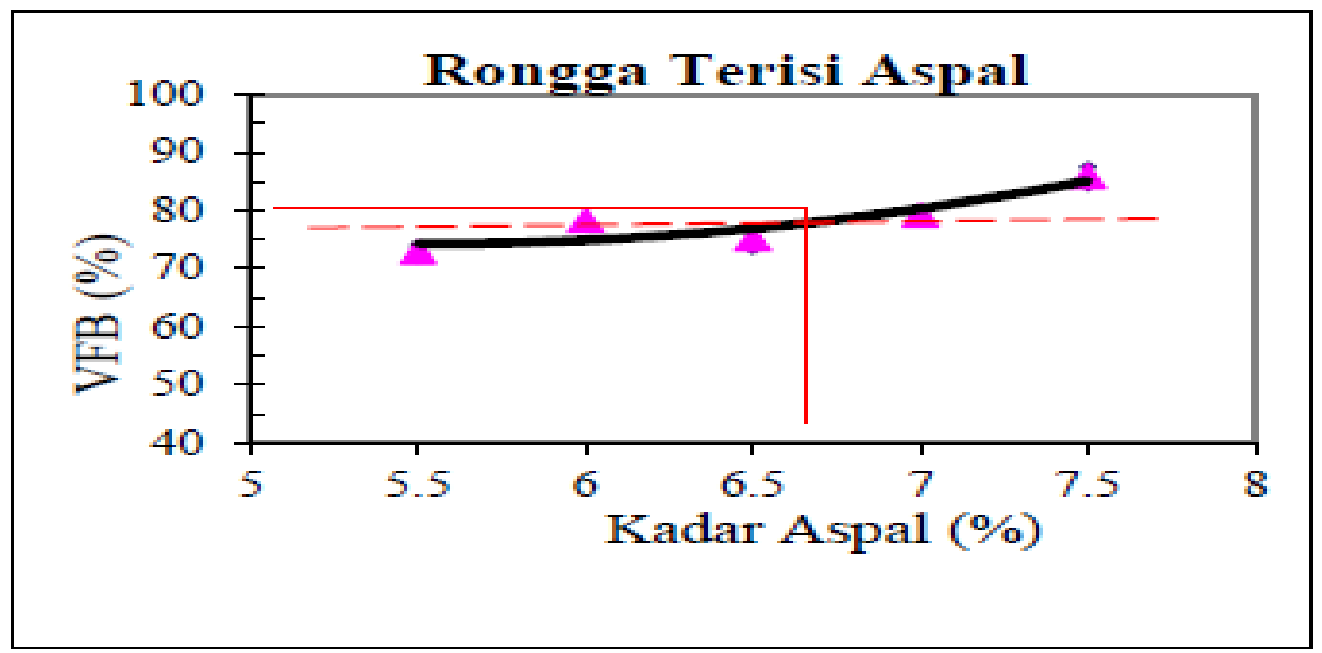

Gambar 5. Hubungan \% Aspal dengan VFB Latasir Konvensional

Batas spesifikasi nilai VFB untuk campuran Latasir yaitu minimal 75\%. Pada campuran konvensional kadar aspal yang memenuhi spesifikasi yaitu pada kadar aspal 6\% - 7,5\% (lihat Gambar 5). 
JURNAL KACAPURI

JURNAL KEILMUAN TEKNIK SIPIL

Volume 2 Nomor 2 Edisi Desember 2019

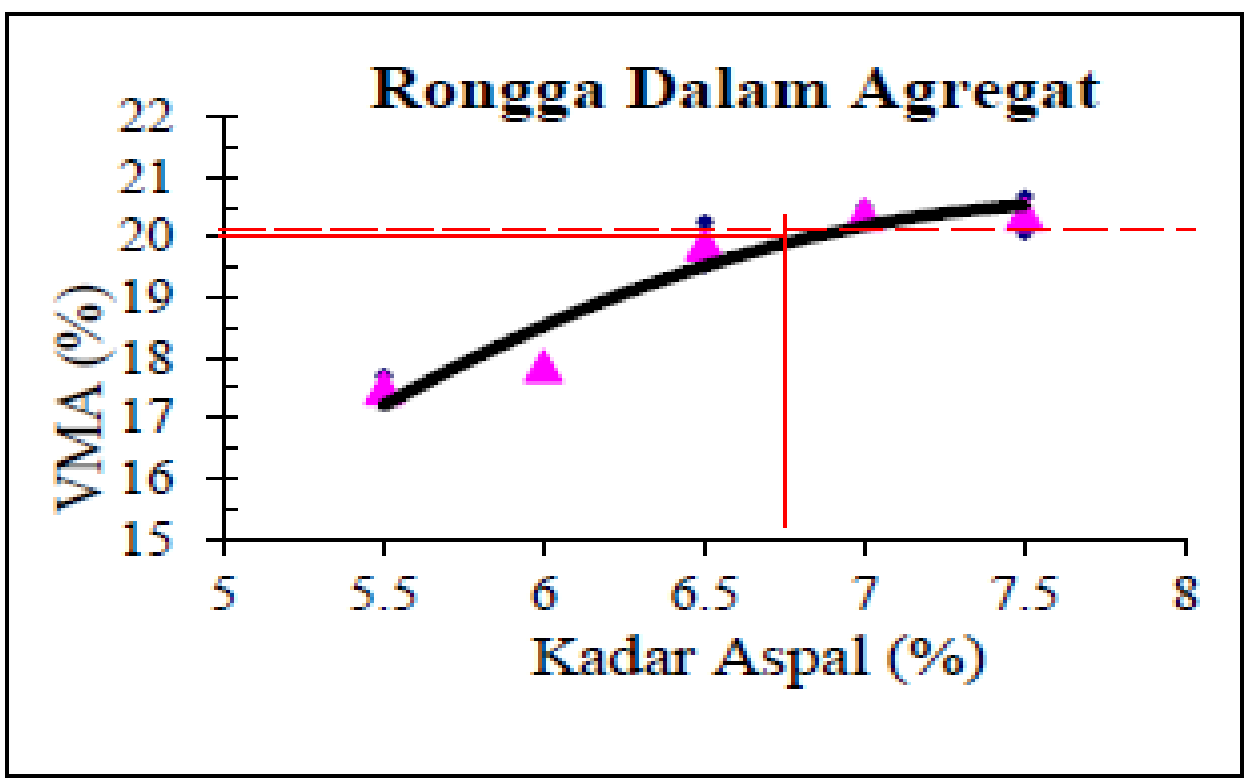

Gambar 6. Hubungan \% Aspal dengan VMA Latasir Konvensional

Batas spesifikasi nilai VMA untuk campuran Latasir yaitu minimal 20\%. Pada campuran konvensional kadar aspal yang memenuhi spesifikasi yaitu pada kadar aspal 7\% - 7,5\% (lihat Gambar 6).

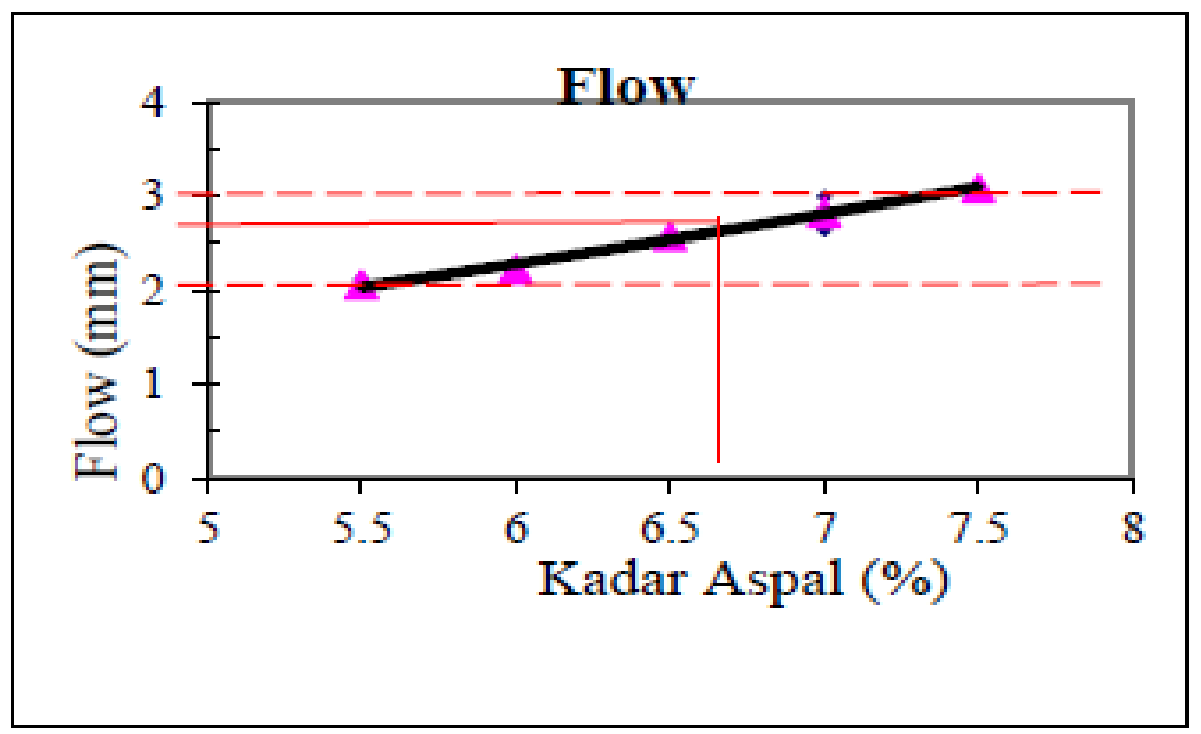

Gambar 7. Hubungan \% Aspal dengan Flow Latasir Konvensional

Batas spesifikasi nilai flow untuk campuran Latasir yaitu minimal $2 \mathrm{~mm}$ dan maksimal $3 \mathrm{~mm}$. Pada campuran konvensional kadar aspal yang memenuhi spesifikasi yaitu pada kadar aspal 5,5\% $-7,5 \%$ (lihat Gambar 7). 
JURNAL KACAPURI

JURNAL KEILMUAN TEKNIK SIPIL

Volume 2 Nomor 2 Edisi Desember 2019

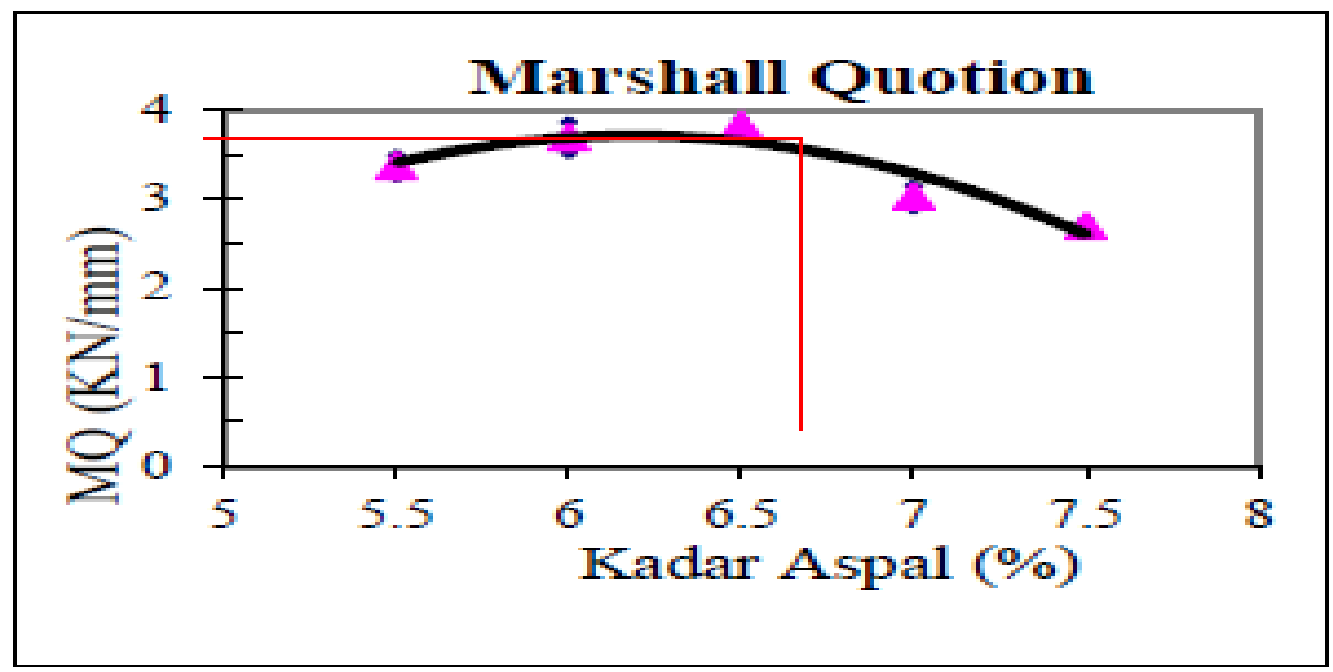

Gambar 8. Hubungan \% Aspal dengan $M Q$ Latasir Konvensional

Batas spesifikasi nilai Marshall Quotient untuk campuran Latasir yaitu minimal $80 \mathrm{~kg} / \mathrm{mm}$. Pada campuran konvensional kadar aspal yang memenuhi spesifikasi yaitu pada kadar aspal 5,5\% 7,5\% (lihat Gambar 8).

Setelah rentang kadar aspal yang memenuhi masing-masing spesifikasi sudah didapatkan maka bisa dibuat bagan seperti pada Gambar 9 untuk menentukan kadar aspal optimumnya.

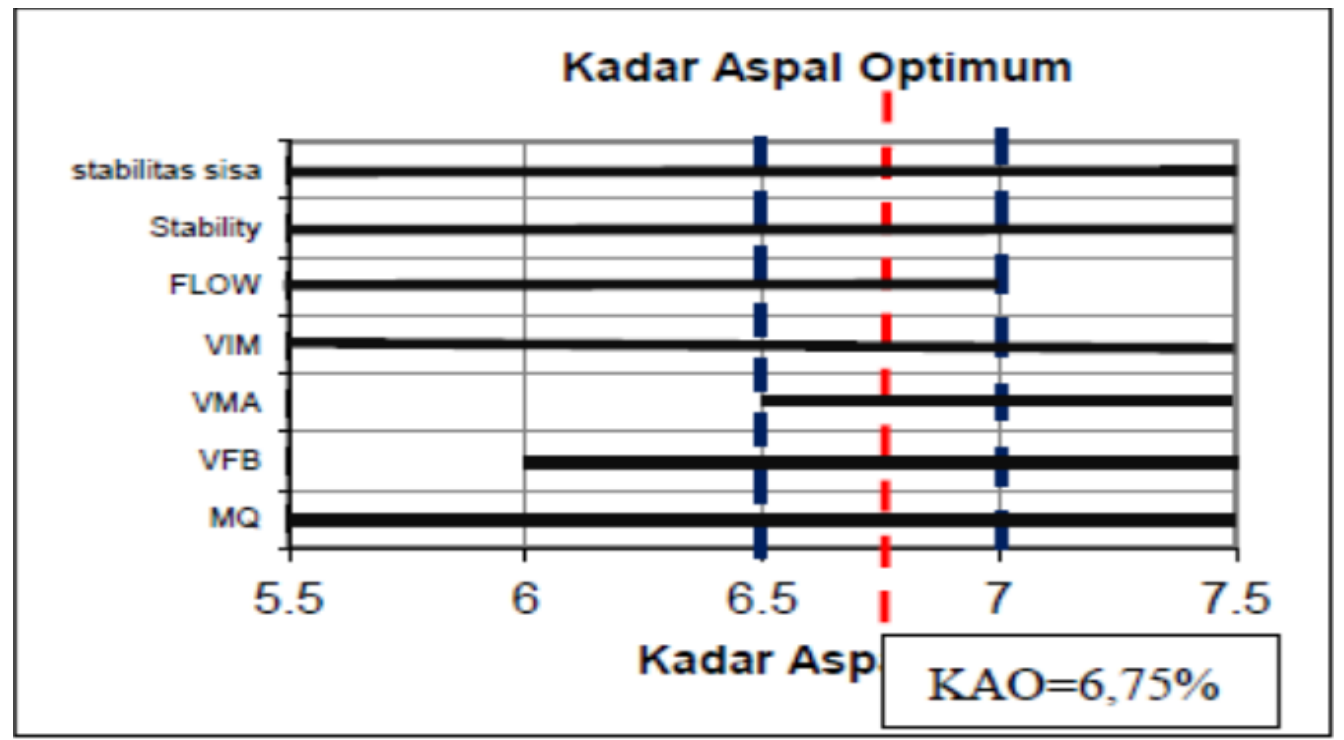

Gambar 9. Bagan Kadar Aspal Optimum

Sehingga didapat nilai kadar aspal optimum yang memenuhi semua spesifikasi adalah 6,5\% - $7 \%$, diambil nilai tengahnya yaitu 6,75\% (lihat Gambar 9). 
JURNAL KACAPURI

JURNAL KEILMUAN TEKNIK SIPIL

Volume 2 Nomor 2 Edisi Desember 2019

Pengaruh penambahan Roadcell-50 pada campuran Latasir adalah hasil analisis hubungan Kadar Aspal Optimum dengan Karakteristik Campuran bisa dilihat pada Tabel 10.

Tabel 10. Hasil Grafik Hubungan Kadar Aspal Optimum dengan Karakteristik Campuran

\begin{tabular}{|c|c|c|c|c|c|c|c|}
\hline \multirow{2}{*}{$\begin{array}{l}\text { Karakteristik } \\
\text { Campuran }\end{array}$} & \multirow[b]{2}{*}{ Spesifikasi } & \multirow{2}{*}{$\begin{array}{c}\text { Konvensional } \\
(6,75 \%)\end{array}$} & \multicolumn{4}{|c|}{ Aditif } & \multirow[b]{2}{*}{ Ket. } \\
\hline & & & $\begin{array}{c}1 \% \\
(6,75 \%)\end{array}$ & $\begin{array}{l}2 \% \\
(7 \%)\end{array}$ & $\begin{array}{c}3 \% \\
(6,75 \%)\end{array}$ & $\begin{array}{c}4 \% \\
(6,75 \%)\end{array}$ & \\
\hline VIM & $3 \%-6 \%$ & 5,49 & 5,5 & 5 & 5,4 & 5,6 & memenuhi \\
\hline VMA & Min. $20 \%$ & 22 & 20 & 21 & 20 & 21 & memenuhi \\
\hline VFB & Min. $75 \%$ & 79 & 77 & 82 & 79 & 77 & memenuhi \\
\hline Stabilitas & Min. $200 \mathrm{~kg}$ & 930 & 990 & 1500 & 1500 & 1450 & memenuh \\
\hline Flow & $2 \mathrm{~mm}-3 \mathrm{~mm}$ & 2,7 & 2,8 & 2,9 & 2,8 & 2,6 & memenuh \\
\hline MQ & Min. $80 \mathrm{~kg} / \mathrm{mm}$ & 350 & 340 & 370 & 500 & 550 & memenuhi \\
\hline
\end{tabular}

Pada pengujian Marshall didapatkan nilai stabilitas dan flow yang lebih tinggi dengan adanya penambahan aditif. Stabilitas yang tinggi menunjukkan penambahan aditif Roadcell-50 bagus digunakan untuk perkerasan yang menahan volume lalu lintas tinggi. Nilai flow yang tinggi menunjukkan deformasi yang tinggi terjadi dari keadaan perkerasan belum mengalami pembebanan sampai beban maksimum tercapai.

Penambahan aditif Roadcell-50 akan mengakibatkan nilai VIM dan VMA meningkat, sementara nilai VFB dan Marshall Quotient (MQ) turun. Nilai VIM yang meningkat atau besar menunjukkan bahwa campuran aspal tidak kedap air dan udara. Hal ini berhubungan dengan daya lekat aspal dengan agregat yang berkurang. Nilai VMA juga mengalami peningkatan. Nilai VMA yang besar menunjukkan kalau aspal mampu menyelimuti agregat dengan baik dan rata. Dengan nilai VIM dan VMA yang besar menunjukkan bahwa campuran aspal memiliki durabilitas yang tinggi. Nilai VFB yang turun menunjukkan kalau daya lekat antara aspal dan agregat menurun. Nilai MQ yang lebih kecil menunjukkan kalau penambahan aditif pada campuran akan mengakibatkan fleksibelitas campuran bertambah dan kekakuannya berkurang.

Pada kadar optimum untuk campuran aspal tanpa penambahan aditif kadar aspal optimumnya sebesar $6,75 \%$, sementara dengan penambahan aditif sebanyak $1 \%$ kadar aspal optimumnya $6,75 \%$, penambahan aditif $2 \%$ kadar aspal optimumnya $7 \%$, penambahan aditif $3 \%$ kadar aspal optimumnya $6,75 \%$, penambahan aditif $4 \%$ kadar aspal optimumnya $6,75 \%$. 
JURNAL KACAPURI

JURNAL KEILMUAN TEKNIK SIPIL

Volume 2 Nomor 2 Edisi Desember 2019

Hasil Pengujian Perendaman adalah pengujian yang bertujuan untuk mengetahui ketahanan campuran terhadap kerusakan oleh air atau yang disebut indeks perendaman. Hasil indeks Perendaman bisa dilihat pada Tabel 11.

Tabel 11. Tabel Indeks Perendaman (Immertion Test)

\begin{tabular}{|c|c|c|c|c|c|c|}
\hline \multirow{2}{*}{\multicolumn{2}{|c|}{ Variasi }} & \multirow{2}{*}{$\begin{array}{c}\text { Stabilitas } \\
\text { (kg) }\end{array}$} & $\begin{array}{c}\text { Stabilitas } \\
\text { Sisa }\end{array}$ & Indeks & \multirow{2}{*}{ Spesifikasi } & \multirow{2}{*}{ Keterangan } \\
\hline & & & (kg) & $\begin{array}{c}\text { Perendaman } \\
(\%)\end{array}$ & & \\
\hline \multirow{2}{*}{\multicolumn{2}{|c|}{ Konvensional }} & \multirow{2}{*}{930} & 845.90 & 90.96 & \multirow{10}{*}{$>90 \%$} & memenuhi \\
\hline & & & 847.17 & 91.09 & & memenuhi \\
\hline \multirow{8}{*}{ Aditif } & \multirow{2}{*}{$1 \%$} & \multirow{2}{*}{990} & 913.19 & 92.24 & & memenuhi \\
\hline & & & 910.56 & 91.98 & & memenuhi \\
\hline & \multirow{2}{*}{$2 \%$} & \multirow{2}{*}{1500} & 1467.11 & 97.81 & & memenuhi \\
\hline & & & 1430.88 & 95.39 & & memenuhi \\
\hline & \multirow{2}{*}{$3 \%$} & \multirow{2}{*}{1500} & 1468.35 & 97.89 & & memenuhi \\
\hline & & & 1357.95 & 90.53 & & memenuhi \\
\hline & \multirow{2}{*}{$4 \%$} & \multirow{2}{*}{1450} & 1328.25 & 91.60 & & memenuhi \\
\hline & & & 1382.53 & 95.35 & & memenuhi \\
\hline
\end{tabular}

Pada pengujian perendaman untuk campuran aspal tanpa penambahan aditif didapat nilai indeks perendaman sebesar 90,96\% dan 91,09\% yang berarti nilai indeks perendaman memenuhi syarat spesifikasi Bina Marga. Dengan penambahan aditif sebesar 1\% nilai indeks perendaman sebesar 92,24\% dan 91,98\%. Dengan penambahan aditif sebesar $2 \%$ nilai indeks perendaman sebesar $97,81 \%$ dan 95,39\%. Dengan penambahan aditif sebesar 3\% nilai indeks perendaman sebesar $97,89 \%$ dan $90,53 \%$. Dengan penambahan aditif sebesar $4 \%$ nilai indeks perendaman sebesar $91,60 \%$ dan $95,35 \%$. Hasil ini menunjukkan penambahan aditif Roadcell-50 bisa menaikkan nilai dari indeks perendaman campuran aspal yang berarti penambahan aditif bisa meningkatkan nilai durabilitas campuran Latasir kelas A.

\section{Kesimpulan}

\section{PENUTUP}

1. Penelitian menunjukkan penambahan aditif Roadcell-50 tidak memiliki pengaruh signifikan pada perubahan kadar aspal optimum, namun memberikan perubahan signifikan pada nilainilai karakteristik campuran tersebut terutama pada nilai stabilitasnya yang meningkat.

2. Hasil ini menunjukkan penambahan aditif Roadcell-50 bisa menaikkan nilai dari indeks perendaman campuran aspal yang berarti penambahan aditif bisa meningkatkan nilai durabilitas campuran aspal Latasir kelas A. 
JURNAL KACAPURI

JURNAL KEILMUAN TEKNIK SIPIL

Volume 2 Nomor 2 Edisi Desember 2019

\section{Ucapan Terimakasih}

Penulis mengucapkan terimakasih kepada rekan sejawat Program Studi Teknik Sipil, Fakultas Teknik, Universitas Lambung Mangkurat dan semua pihak yang telah banyak membantu kelancaran dan selesainya penelitian ini.

\section{DAFTAR PUSTAKA}

Anwar, Rosehan, Ir. MT. (2010). Materi Kuliah Quality Control dan Spesifikasi.

Departemen Pekerjaan Umum. (2008) Spesifikasi Lapis Tipis Aspal Pasir (Latasir). Yayasan Penerbit PU, Jakarta.

Sastromijoyo, Suryatin. (1983). Petunjuk Pelaksanaan Lapis Tipis Aspal Pasir (Latasir). Yayasan Penerbit PU, Jakarta.

Soehartono, Ir. (2001). Teknologi Aspal Dan Penggunaannya Dalam Konstruksi Perkerasan Jalan. Yayasan Penerbit PU, Jakarta.

Spesifikasi Umum edisi November 2010. Direktorat Jenderal Bina Marga Kementerian Pekerjaan Umum.

Sudarsono D.U, Ir. (1997) Rencana Campuran (Mix Design). Yayasan Penerbit PU, Jakarta.

Rahman, Rahmatang.(2003). Studi Pengaruh Penambahan Roadcell-50 Terhadap Karakteristik Campuran Lapis Tipis Beton Aspal (HRS-WC) 